\title{
An Empirical Analysis on the Capital Structure and Its Influencing Factors of the Listed Companies--Take China's Thermal Power Industry as an Example
}

\author{
Jianfei Shen", a, Yanru Lin ${ }^{1, b}$ \\ ${ }^{1}$ North China Electric Power University, Beijing, China. \\ ashenjianfei@263.net.cn, bfjlinyanru@126.com
}

\begin{abstract}
In 2015, "Electricity Reform No. 9" announced that the reform of China's power companies entered a new phase. Under the new power reform, capital integration involving the reorganization measures taken in response to overcapacity on the supply side, or the capital needs involved in power grid planning and construction, needs to be established in understanding the current capital structure characteristics of the power industry and its influencing factors. China is dominated by thermal power generation. Therefore, this study selected 29 annual reports of listed companies in the thermal power industry from 2014 to 2016 as research samples and constructed a multiple linear regression model to analyze the current status of capital structure of listed companies in China's thermal power industry and its influencing factors. The research shows that: (1) The capital structure of thermal power industry in China presents the characteristics of "high asset-liability ratio but the trend is overall downward, external financing dominated by debt financing, and supplemented by internal financing led by depreciation financing". (2) Operational ability and short-term solvency are negatively related to the capital structure of thermal power industry. (3) The growth capacity and asset residual guarantee value are positively related to the capital structure of thermal power industry. (4) The company's scale, profitability, and non-debt tax shield have no significant effect on the capital structure of thermal power industry. Finally, on the basis of the research conclusions, this paper puts forward proposals for the supply-side reform and power grid planning and construction of thermal power industry from the perspective of capital structure.
\end{abstract}

Keywords: Thermal power industry, capital structure, influencing factors.

\section{Research Background}

In 2015, the "Electricity reform No. 9 Document" announced that the long-silent electricity enterprise reform has set off a new wave. In recent years, the economic growth rate has slowed down, and the growth rate of social power consumption has dropped. However, the generation-side staking area represented by thermal power has not stopped. This has led to the rapid arrival of the oversupply era in China. Therefore, in July 2016, the State Council promulgated the "Guiding Opinions on Promoting the Adjustment and Restructuring of Central Enterprises" and clearly stated that it would promote the merger and reorganization of the power industry. In 2017, the Deputy Director of the National Development and Reform Commission, Ming Jimi, also pointed out that the thermal power industry must adopt various methods to carry out supply-side reforms this year, including a number of capacity-reduction methods such as elimination, reorganization, and transformation. As a result of the news of mergers and reorganizations of various electric power companies, we will find that: merger and reorganization of enterprises is not a simple superposition of corporate assets, but the effect of improving efficiency through the reconfiguration of resources. No matter what kind of restructuring, restructuring is only the first step. After that, it is more crucial to capital integration, resource integration, strategic integration, management integration, and cultural integration.

In addition to excess capacity on the supply side, another major challenge faced by the development of power companies is that the construction of power grids cannot keep up with the development of power supply. In some regions, there is a situation where there is no electricity transmission. The expansion and upgrading of the power grid has become one of the major tasks of the current power reform. To accomplish this task, it is necessary to inject large amounts of capital 
into power companies. The source of funds should not be limited to existing loan methods and public financing. It is a prerequisite for understanding the capital structure of power companies.

Under the new power reform, whether for the supply side of the excess capacity to take the reorganization measures involved in the capital integration, or the power grid planning and construction involved in the funding needs are based on an understanding of the characteristics of existing capital structure of the power industry and its influencing factors.

Only by understanding the capital structure and its influencing factors can we better remove production capacity and plan the power grid, which will be conducive to the smooth implementation of the new round of reform of the power companies. In addition, China's power industry is dominated by thermal power generation, and there are significant differences in various power generation methods. Although the state encourages the development of clean energy, as of the end of 2016, the proportion of thermal power generation was still as high as $74.4 \%$. In the past, most of the samples selected for analysis of the capital structure of the power industry were all power companies, and the power generation methods were not differentiated. The results of the analysis may not be typical. In this context, this paper selects listed companies in the thermal power industry as research samples, studies the current status of listed companies' capital structure and their influencing factors in China's thermal power industry, and tries to provide comparatively typical capital structure data for the smooth implementation of the new round of power company reforms.

\section{Literature Review of Capital Structure Theory}

\subsection{Capital Structure Theory}

The theory of capital structure is based on the goal of maximizing the value of the company, focusing on the effect of changes in the proportion of debt capital and equity capital on the value of the firm in the capital structure. The beginning of modern capital structure theory is the MM theory proposed by American scholars Modigliani and Miller in 1958. Subsequently, in the MM theory, the financial distress trade-off theory, the financing order theory, the incentive theory, the agency cost theory, the signal transmission theory and the control theory were introduced to make the MM theory more perfect and the conditions for application become wider. A reasonable capital structure can not only improve the corporate governance structure, properly reduce corporate financial risks, and adjust corporate financing costs, but also can achieve the purpose of improving corporate value. This is also a reflection of the role of capital structure optimization.

Capital structure has broad and narrow sense. The generalized capital structure refers to the proportionate relationship between all debt capital and equity capital in the capital source of a company; the narrowly defined capital structure refers to the proportional relationship of various long-term capital sources of an enterprise. Empirical research abroad mainly uses the long-term debt ratio of assets. According to Han Chicano (2006), China should adopt a generalized capital structure. Commonly used indicators for measuring capital structure are: total liabilities/total assets, long-term liabilities/total assets, long-term liabilities/equity, total liabilities/equity, equity/total assets. In the empirical study of the basic theory and economic effects of capital structure, almost the first indicator is used, namely, total liabilities/total assets; in the empirical study of the capital structure influencing factors, the first two are commonly used [1]. According to past research literature, the main factors affecting the capital structure of a company can be summarized into nine: industry characteristics, capital markets, company size, profitability, operational capacity, growth capacity, solvency, asset guarantee residual value, and non-debt tax shields. Most of the articles are built on the multiple regression linear model to study the influence of various factors on the capital structure of the company [2].

Therefore, based on previous research results and the characteristics of China's thermal power industry, this paper analyzes the use of generalized capital structure, total liabilities/total assets, that is, the asset-liability ratio to measure the capital structure of the company, select company size, profitability, operating capacity, the growth capability, debt repayment ability, asset guarantee value, 
and non-debt taxation shield as factors affecting the capital structure and construct a multiple regression linear model.

\subsection{Research Status of Capital Structure of Electric Power Industry}

The development of China's power industry has its own unique political and economic backgrounds. For example, the initial development was under heavy macro-control, with the development of the market economy, the proportion of state funding in the power industry has gradually declined, and the ratio of loans and foreign capital has gradually increased. The capital construction funds in the power industry have gradually improved, and China's power industry itself has exhibited the characteristics of capital structure that is dominated by exogenous financing and supplemented by intrinsic financing, and the asset-liability ratio have shown an upward trend year by year. At present, there are still some drawbacks and deficiencies in the capital structure and financing strategy of China's power industry.

Ma Qiujun and Pang Minogue (2007) systematically analyzed the security financing structure, equity financing structure, and capital structure data of 30 listed companies in China's power industry and concluded that the capital structure of listed companies in China's power industry presented "leadership of foreign financing with priority to liabilities. The characteristics of endogenous financing based on depreciation financing are paved [3].

Zhou Yunnan (2011) studied 55 listed companies in the power industry and concluded that China's power industry has high asset-liability ratios, unreasonable debt structure, and the huge loss of debtpaying power of thermal power companies. It was pointed out that these characteristics were caused by the high growth rate of electric power companies, low profitability, rising interest rates, single financing channels, and unreasonable ownership structure [4].

\section{Empirical Research Design}

\subsection{Proposition of Research Hypothesis}

Based on the financial theory and previous research results, combined with the actual situation of China's thermal power industry listed companies, this paper proposes the following seven theoretical assumptions:

Hypothesis 1: The company size is positively related to the capital structure. Large-scale enterprises are more stable, have stronger anti-risk capabilities, are less likely to be bankrupt, and have stronger credit capabilities; what's more large companies have the ability to diversify their operations and can diversify and reduce their operational risks. Therefore, large companies have more liabilities than small businesses.

Hypothesis 2: Negative correlation between profitability and capital structure. According to the financing order theory, the general order of corporate financing is retained earnings, debt financing, and equity financing. When enterprises are more profitable, the more companies have available surpluses, they can use less debt financing.

Hypothesis 3: The operational capacity is negatively related to the capital structure. When the company's operating capacity is better, the use of assets is more efficient, and the ability of enterprises to use assets to create profits is stronger, and the more retained earnings the company can use. That can rely less on debt financing.

Hypothesis 4: Short-term solvency is negatively related to capital structure. When the short-term solvency of the company is good, it indicates that the company's working capital is relatively abundant (current ratio = current assets / current liabilities, working capital = current assets - current liabilities), and the external financing requirements of the company are low.

Hypothesis 5: Growth capacity is positively related to capital structure. In the early stages of growth, corporate capital needs are large, but there are few supply channels for funds. In the early stage of development, it is difficult for domestic companies to meet the development needs. Therefore, companies with strong growth potential tend to choose external financing. 
Assumption 6: Asset guarantee residual value is positively related to the capital structure. With a large asset guarantee residual value, companies can provide more tangible asset guarantees for creditors, reduce the cost of corporate financial distress, and increase credit capacity. Therefore, the higher asset guarantees residual value, the stronger the corporate debt financing ability.

Hypothesis 7: The non-debt tax shield is positively related to the capital structure. Liabilities can be tax deductible, and some non-liability items, such as depreciation, can be set aside before tax, which also has a tax deduction effect. The electric power industry has large fixed assets, and the depreciation tax shield is very large. This will increase the income of the creditors. Corporate debt financing is relatively simple, so the non-debt tax shield is positively related to the capital structure.

\subsection{Study Variable Setting and Model Construction}

According to the above assumptions, this paper uses the asset-liability ratio as an explanatory variable to conduct empirical research, and selects company size, profitability, operational capacity, growth capacity, solvency, asset guarantee value, and non-debt tax shield from financial indicators as an explanation. Variable [5]. The symbols and definitions of variables are shown in Table 1.

Table 1. Variable definitions

\begin{tabular}{|c|c|c|c|}
\hline Project & Financial indicator & $\begin{array}{l}\text { Variable } \\
\text { symbol }\end{array}$ & Calculation formula \\
\hline Capital Structure & the asset-liability ratio & LEV & Total liabilities/total assets \\
\hline Company Size & $\begin{array}{l}\text { Natural logarithm of total } \\
\text { assets }\end{array}$ & SIZE & $\begin{array}{c}\text { Take the natural logarithm of total } \\
\text { assets }\end{array}$ \\
\hline Profitability & Return on net assets & ROE & Net profit / average owner's equity \\
\hline Operating capacity & Turnover of total assets & $\mathrm{CA}$ & $\begin{array}{c}\text { Main business income/ average total } \\
\text { assets }\end{array}$ \\
\hline Growth ability & $\begin{array}{c}\text { Growth rate of total } \\
\text { assets }\end{array}$ & GROWTH & $\begin{array}{l}\text { Asset Increment/Total Assets at the } \\
\text { beginning of the year }\end{array}$ \\
\hline Solvency & Current ratio & CR & Current assets / current liabilities \\
\hline $\begin{array}{l}\text { guarantee residual } \\
\text { value }\end{array}$ & $\begin{array}{l}\text { Ratio of inventory and } \\
\text { fixed assets }\end{array}$ & GRV & $\begin{array}{c}(\text { Inventory }+ \text { Fixed Assets }) / \text { Total } \\
\text { Assets }\end{array}$ \\
\hline $\begin{array}{l}\text { Non-debt tax } \\
\text { shield }\end{array}$ & $\begin{array}{l}\text { Depreciation of fixed } \\
\text { assets }\end{array}$ & NDTS & $\begin{array}{c}\text { Depreciation of fixed assets / total } \\
\text { assets }\end{array}$ \\
\hline
\end{tabular}

Based on the above assumptions and variable settings, this article builds a multiple linear regression model as follows:

$$
\mathrm{LEV}=\beta 0+\beta 1 \mathrm{SIZE}+\beta 2 \mathrm{ROE}+\beta 3 \mathrm{CA}+\beta 4 \mathrm{GROWTH}+\beta 5 \mathrm{CR}+\beta 6 \mathrm{GRV}+\beta 7 \mathrm{NDTS}+\mathcal{E}
$$

Among them, the variable names are shown in Table $1, \beta 1, \beta 2, \beta 3, \beta 4, \beta 5, \beta 6, \beta 7$ are regression coefficients, $\beta 0$ for the intercept term, $\varepsilon$ is a random interference term.

\subsection{Sample Selection and Data Sources}

Based on the "Guidelines for the Industry Classification of Listed Companies" promulgated by the China Securities Regulatory Commission in October 2012, this article has obtained 34 listed thermal power generation companies in Shanghai and Shenzhen, excluding ST, ST*, and no continuing operations related to 2014-2016. Listed companies with data shortages or data anomalies eventually obtained 87 sample data from 29 thermal power listed companies from 2014 to 2016.

This article mainly collects relevant financial data of the company from Jucar Consulting Network, Great Wall Securities official website and the websites of listed companies. When processing and analyzing data, this article uses statistical software SPSS20.0 and Excel 2015. 


\section{Empirical Analysis}

\subsection{Research Status of Capital Structure of Electric Power Industry}

1. The asset-liability ratio is higher but the overall trend is declining.

In recent years, the high debt ratio risk in the power industry has continued and it has entered the stage of rising risk [3]. As shown in Figure 1, the asset-liability ratio of the sample companies is mostly distributed between $40 \%$ and $70 \%$, but the proportion of companies with asset-liability ratios above $70 \%$ is as high as $37 \%$, indicating that the asset-liability ratio of China's thermal power industry is high. As Zhou Yunnan (2011) analyzed, thermal power companies have a high cost increase, coal price linkage mechanism is not in place, and electricity prices do not reflect the cost of electricity. This has led to a further increase in the loss of the power industry, making it more difficult to operate. In particular, the sharp decline in the profitability of listed power companies led by the five major corporations led to a further rise in corporate asset-liability ratios [4]. However, from the development trend of the sample company's asset-liability ratio in Figure 2, the asset-liability ratio of thermal power industry shows a steady decline.

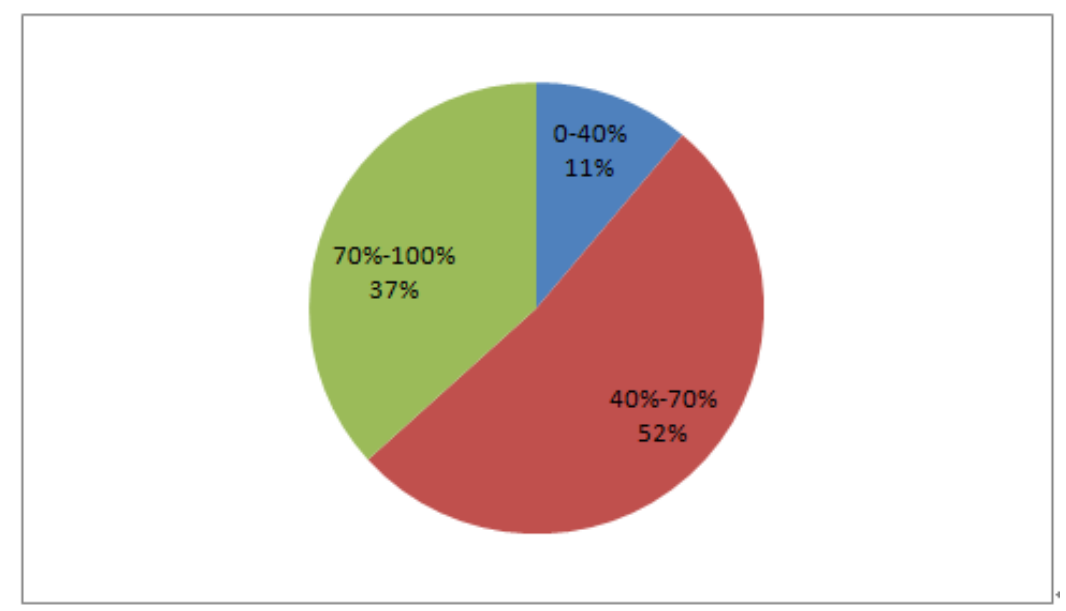

Fig 1. Distribution of assets and liabilities of sample companies

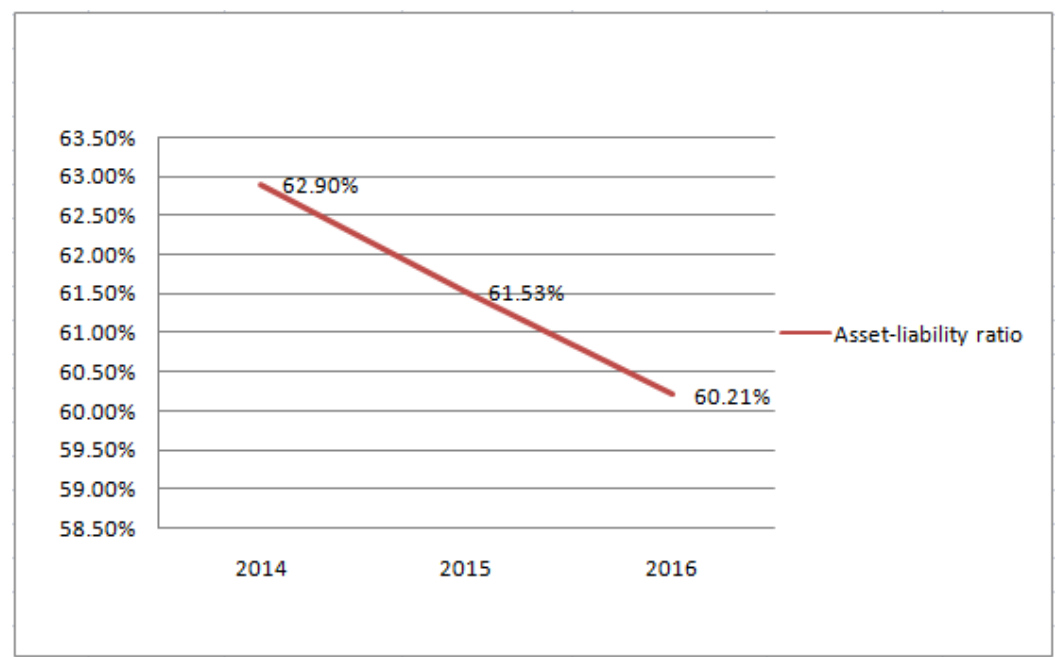

Fig 2. Trends in asset-liability ratios of sample companies

2. Presenting the characteristics of "the main source of foreign financing dominated by debt financing and supplemented by internal financing led by depreciation financing"

The capital of listed companies mainly comes from three aspects: self-owned funds and the accumulation of operation (depreciation and retained earnings); Use capital markets for equity financing (share capital and capital reserves); use bank and other financial institutions for debt 
financing (mainly short-term and long-term loans and bonds payable). The first is internal financing, the latter two are external financing [6].

Table 2. Sample Internal and External Sources of Financing

\begin{tabular}{cccccccc}
\hline project & $\begin{array}{c}\text { external } \\
\text { Financing }\end{array}$ & $\begin{array}{c}\text { debt } \\
\text { Financing }\end{array}$ & $\begin{array}{c}\text { Equity } \\
\text { Financing }\end{array}$ & $\begin{array}{c}\text { internal } \\
\text { Financing }\end{array}$ & depreciation & $\begin{array}{c}\text { Retain } \\
\text { earnings }\end{array}$ & total \\
\hline $\begin{array}{c}\text { capital } \\
\text { structure }\end{array}$ & $68.97 \%$ & & & $31.03 \%$ & & & $100 \%$ \\
& & $81.67 \%$ & $18.33 \%$ & & $85.19 \%$ & $14.81 \%$ & \\
\hline
\end{tabular}

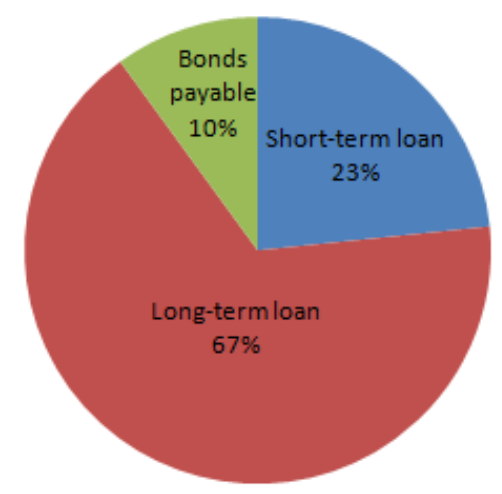

Fig 3. Distribution of debt financing of sample companies

As shown in Table 2, among the sample companies, external financing companies accounted for $68.97 \%$, while internal financing companies accounted for $31.03 \%$. Of the external financing companies, $81.67 \%$ accounted for debt financing; as shown in Figure 3, debt financing was mainly long-term loan, and bonds payable accounted for only $10 \%$. Of the companies with intrinsic source of financing, companies with depreciation financing accounted for 85.19. This shows that the capital structure of China's thermal power industry is characterized by "the source of external financing dominated by debt financing and supplemented by internal financing led by depreciation financing." This feature is consistent with the research of Ma Qiujun and Pang Minogue (2007).

\subsection{Analysis of Factors Influencing the Capital Structure of the Electric Power Industry}

\subsubsection{Descriptive Statistics}

Table 3. Descriptive statistics

\begin{tabular}{cccccc}
\hline & $\mathrm{N}$ & Min & $\max$ & Mean & Standard deviation \\
\hline LEV & 87 & 33.15 & 88.26 & 61.9118 & 14.94072 \\
SIZE & 87 & 12.85 & 17.45 & 14.9261 & 1.17869 \\
ROE & 87 & -7.33 & 34.54 & 10.7434 & 7.69506 \\
GROWTH & 87 & -23.12 & 90.30 & 10.7767 & 18.56289 \\
CA & 87 & .04 & 1.01 & .3890 & .15944 \\
GRV & 87 & .08 & .86 & .5943 & .13941 \\
NDTS & 87 & .05 & .92 & .3732 & .17082 \\
CR & 87 & .13 & 2.15 & .6627 & .43567 \\
Valid N (list status) & 87 & & & & \\
\hline
\end{tabular}

Table 3 shows that the standard deviation of company size, operating capacity, and asset guarantee residual value, non-debt tax shield, and solvency are relatively small. This shows that there is little difference in the company's thermal power industry's company scale, operating capacity, asset guarantee residual value, non-debt tax shield, and solvency during 2014-2016. The standard deviations of asset-liability ratio, net asset return rate, and total asset growth rate were 14.94, 7.69, 
and 18.56, respectively indicating that the capital structure, profitability, and growth ability of China's thermal power industry are quite different.

\subsubsection{Correlation Analysis}

Prior to regression analysis, this paper first performed a Pearson correlation test on each variable and analyzed the correlation between variables. In general, the absolute value of the correlation coefficient between 0-0.2 indicates irrelevant or very weak correlation, 0.2-0.4 indicates weak correlation, 0.4-0.7 indicates moderate correlation, and 0.7-1 indicates high correlation. If the correlation coefficient between variables is greater than 0.5 , the introduction of these variables into the same model may lead to multiple collinearity, which may lead to unsatisfactory model fitting results. At this time, tests should be conducted to eliminate the problem of multicollinearity.

Table 4. Correlation Analysis

\begin{tabular}{|c|c|c|c|c|c|c|c|c|c|}
\hline & \multirow[t]{2}{*}{ LEV } & \multicolumn{2}{|c|}{ SIZE } & \multirow{2}{*}{$\begin{array}{l}\mathrm{ROE} \\
-.150\end{array}$} & \multirow{2}{*}{$\begin{array}{l}\mathrm{CA} \\
-.338^{* *}\end{array}$} & \multirow{2}{*}{$\begin{array}{c}\mathrm{CR} \\
-.495^{* *}\end{array}$} & \multirow{2}{*}{$\frac{\text { GROWTH }}{.033}$} & \multirow{2}{*}{$\begin{array}{l}\text { GRV } \\
.509^{* *}\end{array}$} & \multirow{2}{*}{$\begin{array}{c}\text { NDTS } \\
.198\end{array}$} \\
\hline LEV & & 1 & .198 & & & & & & \\
\hline SIZE & & .198 & 1 & -.130 & $-.435^{* *}$ & $-.282 * *$ & -.168 & -.039 & -.094 \\
\hline ROE & & -.150 & -.130 & 1 & $.354 * *$ & -.003 & .061 & .146 & .088 \\
\hline $\mathrm{CA}$ & & $-.338 * *$ & $-.435 * *$ & $.354 * *$ & 1 & $.255^{*}$ & -.121 & .123 & $.282 * *$ \\
\hline CR & & $-.495 * *$ & $-.282 * *$ & -.003 & $.255^{*}$ & 1 & .181 & $-.454 * *$ & -.146 \\
\hline GROWTH & & .033 & -.168 & .061 & -.121 & .181 & 1 & $-.241^{*}$ & $-.219 *$ \\
\hline GRV & & $.509 * *$ & -.039 & .146 & .123 & $-.454 * *$ & $-.241^{*}$ & 1 & $.401 * *$ \\
\hline \multirow[t]{2}{*}{ NDTS } & & . 198 & -.094 & . 088 & $.282 * *$ & -.146 & $-.219^{*}$ & $.401 * *$ & 1 \\
\hline & \multicolumn{9}{|c|}{$\begin{array}{l}\text { **. Significantly related on the } .01 \text { level (both sides). } \\
\text { *. Significantly related at the } 0.05 \text { level (bilateral). }\end{array}$} \\
\hline
\end{tabular}

As can be seen from Table 4, with the exception of the asset-liability ratio, the absolute values of the correlation coefficients of the variables are all between 0.003 and 0.495 , indicating that each variable has good independence and can basically exclude the effects of multicollinearity between variables. The correlation coefficients of total asset growth rate, current ratio and debt ratio were 0.338 and -0.495 , which were significant at the $1 \%$ level. This shows that operational capacity and short-term solvency are negatively correlated with capital structure. Hypotheses 3 and 4 were initially verified. The correlation coefficient between the asset guarantee residual value and the asset-liability ratio was 0.509 , which was significant at the $1 \%$ level. This indicates that the asset guarantee residual value is positively related to the asset structure. Hypothesis 6 is initially verified. The correlation of other variables is not significant. However, whether the final assumption is true requires further verification.

\subsubsection{Analysis of Regression Results}

It can be seen from Table 5 that the $\mathrm{R}$ value of the model is 0.5 , the adjusted $\mathrm{R}$ value is 0.455 , the F statistic is 11.27 , and the significance level is less than $1 \%$, which indicates that the model has goodness of fit. The overall linear relationship between variables and independent variables is significant, so the model can reasonably reflect the impact of various factors on the capital structure.

From Table 5, it can also be seen that the standard coefficient of operating capacity and debt ratio is -0.275 , and the significance level is less than $1 \%$. This shows that operational capacity and shortterm solvency are negatively related to capital structure. Enterprises use assets to create profits. The stronger the ability, the more retained earnings available for use, and the less dependent on debt financing, Assumption 3 holds. The standard coefficient of current ratio and debt ratio is -0.213 , and the significance level is less than $5 \%$. This shows that the short-term solvency is negatively related to the capital structure. When the solvency is better, the working capital of the company is more abundant, and the external financing requirements for the company are lower. Assumption 4 is established. The standard coefficient of total assets growth rate and asset-liability ratio is 0.196 and the significance level is less than $5 \%$. This shows that the growth capacity of enterprises is positively related to the capital structure. The funds for fast-growing companies are in great demand and the 
internal retained funds are difficult to meet the development demand, so relying on debt financing, hypothesis 5 is established. The standard coefficient of asset guarantee residual value and assetliability ratio is 0.469 , and the significance level is less than $1 \%$. This shows that the guarantee residual value is positively related to the capital structure. The company has more tangible assets to provide guarantees and can reduce the occurrence of financial cost and increase credit capacity, the stronger corporate debt financing capability will be strong, Hypothesis 6 is established. The scale of companies, profitability and non-debt tax shields have no significant effect on capital structure.

Table 5. Regression Results of Capital Structure Influencing Factors Model

\begin{tabular}{|c|c|c|c|c|c|}
\hline \multirow{2}{*}{ model } & \multicolumn{2}{|c|}{ Non-standardized coefficient } & \multirow{2}{*}{$\begin{array}{c}\text { Standard coefficient } \\
\text { trial version }\end{array}$} & \multirow{2}{*}{$\mathrm{t}$} & \multirow{2}{*}{ Sig. } \\
\hline & B & Standard error & & & \\
\hline (constan) & 32.244 & 21.615 & & 1.492 & .140 \\
\hline SIZE & .801 & 1.182 & .063 & .678 & .500 \\
\hline ROE & -.263 & . 169 & -.136 & -1.559 & .123 \\
\hline CA & -25.795 & 9.627 & -.275 & -2.679 & .009 \\
\hline $\mathrm{CR}$ & -7.298 & 3.370 & -.213 & -2.165 & .033 \\
\hline GROWTH & .158 & .070 & .196 & 2.256 & .027 \\
\hline GRV & 50.252 & 10.697 & .469 & 4.698 & .000 \\
\hline NDTS & 10.319 & 7.931 & .118 & 1.301 & .197 \\
\hline \multirow[t]{5}{*}{ R Square } & & .500 & & & \\
\hline & & ust R Square & .455 & & \\
\hline & \multicolumn{2}{|c|}{ F-statistic11 } & .270 & & \\
\hline & \multicolumn{2}{|c|}{ Sig } & .000 & & \\
\hline & \multicolumn{2}{|l|}{$\mathrm{N}$} & 87 & & \\
\hline
\end{tabular}

\section{Research Conclusions and Recommendations}

\subsection{Conclusion}

1. The capital structure of China's thermal power industry is characterized by "high asset-liability ratio but the overall trend is downward, dominated by debt finance-led external financing, and supplemented by depreciated financing-led internal financing”. This shows that China's thermal power industry has too high a level of debt, financial risks, and relatively simple financing channels.

2. The thermal power industry's operating capacity and short-term solvency are negatively related to the capital structure. The level of operating capacity and short-term solvency is closely related to the internal surplus funds of the company. The two are negatively related to the capital structure, which shows that China's thermal power industry pays more attention to internal financing.

3. The growth capacity of the thermal power industry and asset guarantee residual value are positively related to the capital structure. China's thermal power industry has developed rapidly in recent years, with large capital requirements. As a state-owned enterprise has a better reputation, it can provide more tangible asset guarantees, so debt financing is relatively easy. This is also an important reason for the high debt ratio of the thermal power industry.

4. The size, profitability, and non-debt tax shield of the thermal power industry have no significant effect on the capital structure. This is very different from the conclusions of scholars such as Hong Jixi and Sheen Yeung (2000) [7], which shows that the company's scale, profitability and non-debt tax shield have significant impact on the capital structure of the entire listed company but have limited impact on the thermal power industry.

\subsection{Suggestions}

1. Fully use various financing methods such as bonds to expand financing channels. The assetliability ratio in the thermal power industry is too high. The main source of funding is long-term borrowing in debt financing and the financing channel is single. With the strengthening of power grid 
construction, the capital demand for thermal power industry has become greater. At the same time, bonds have played an increasingly important role in the gradual diversification of China's power financing channels. The power industry can rely on its industry strengths and credibility to strengthen the power of bond financing and make full use of the corporate bond market to directly fund the community. In addition, the thermal power industry can expand its financing channels through the addition of its own capital, financial leasing, share allotment, issuance of new shares, and the introduction of foreign capital, which also can optimize capital structure and reduce its financial risks.

2. Strengthen the management of tangible assets and effectively use financial leverage to increase the market value of the company. The previous study found that the asset guarantee residual value of listed companies in China's thermal power industry has the most significant impact on their capital structure. Therefore, to strengthen the management of the capital structure, it is necessary to strengthen the management of the company's inventory and fixed assets and other tangible assets. Effective use financial leverage to maximize the value of the company.

3. Comprehensively consider all factors and optimize capital structure. Factors that affect the capital structure are macro factors and micro factors. Among them, company characteristics such as operational ability, short-term debt repayment ability, growth ability, and asset residual value are important components of micro factors. These factors have an impact on the capital structure [8]. Therefore, the thermal power industry must consider the impact of these factors on optimizing the capital structure in the process of capital integration for capacity elimination. Such as the reasonable control of the expansion of the company's scale, maintaining proper asset liquidity, improving the company's profitability, and strengthening the awareness of the owners and operators in the optimization of their capital structure.

\section{References}

[1]. Han Chicano, Sun Qingxia. Thinking of empirical research methods of capital structure in China. Accounting research. 9 (2006) p.42-44.

[2]. Ming Xiangpo, Jiang Yawing. Empirical analysis of capital structure of listed companies in power industry based on SPSS. [J] Securities trading and listed companies. 11(2011) p.51-53.

[3]. Ma Qiujun, Peng Ming. Capital structure characteristics and optimization analysis of Chinese power industry listed companies. [J] Economics and Management Studies, 10 (2007).

[4]. Zhou Yunnan, Goo Yong. The current situation, reasons and optimization measures of capital structure of power listed companies. [J] Journal of Hungnam University of Nationalities (Natural Science Edition) .30(2011) p.118-120.

[5]. Wu Jibe, Li Wending. Research on the determinants of capital structure of Chinese power industry listed companies. [J] Journal of Economic Research.20 (2012) P.92-94.

[6]. Li Yu, Xu Yoke. The micro-foundation of financial system: An analysis of endogenous and exogenous financing structure and profitability of Chinese enterprises. Finance and Economics.12 (2007) p.44-47.

[7]. Hong Jixi, Shen Yi Feng. Empirical analysis on the determinants of capital structure of Chinese listed companies. [J] Journal of Xiamen University: Philosophy and Social Sciences Edition, 3(2000) p.114-120.

[8]. Feng Ron fang, Goo Changwon. Analysis of the factors influencing the capital structure of listed companies take the power industry as an example. $[\mathrm{J}]$ Accounting and corporate governance, 21(2015) p.66-68. 